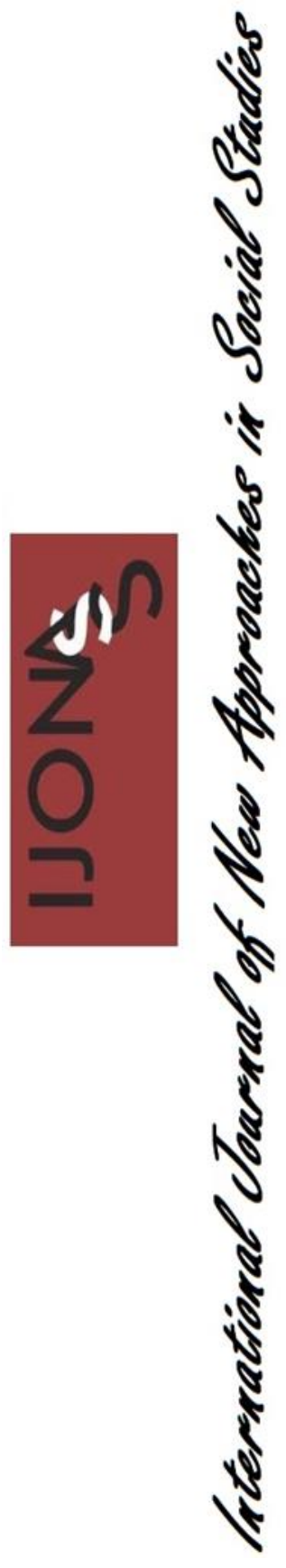

\title{
Ortaokul ve İmam Hatip Ortaokulları Matematik Ders Kitaplarında Yer Alan Kök Değerlerin Incelenmesi
}

\author{
Tuğba KILCAN ${ }^{1 *}(0)$
}

Gönderilme Tarihi: 26 Ekim $2020 \quad$ Kabul Tarihi: 20 Kasım 2020

DOI: $10.38015 /$ sbyy. 816641

\begin{abstract}
$\ddot{O} z:$
Insanların toplum içerisinde sağlıklı, huzurlu, mutlu bir şekilde yaşayabilmesi o toplum için belirlenmiş hukuk kurallarının yanı sıra toplumun benimsediği, içselleştirdiğ $i$ ve gelecek kuşaklara da aktarmak istediği dĕgerlerin varlı̆̆ ile mümkündür. Değerler genel manada insanlar tarafindan sergilenen davranış ya da davranış kalıpları hakkında bir sonuca varmada belli bir standart ortaya atan ve toplumu oluşturan kişilerin birbirleriyle duygusal açıdan bağlllıkları ile meydana gelmiş genelleştirilmiş davranış prensipleri olarak tanımlanmaktadır. Bu şekilde tanımlanan değerlerin gelecek kuşaklara aktarllmasında ĕgitim kurumlarının ve bu kurumlarda okutulan ders kitaplarının payı büyüktür. Çünkü ders kitaplarl, ögretim programlarında yer alan kazanımların aktarımına aracılık ettikleri gibi değer eğitimine de yardımcı olan materyaller olarak görülmektedirler. Bu bağlamda mevcut çalışmada, ortaokul ve imam hatip ortaokulları için hazırlanan matematik ders kitaplarının kök dĕgerler açısından incelenmesi amacıyla gerçekleştirilmiştir. Nitel araştırma yöntemine uygun olarak tasarlanan çalışmada veri toplama amaclyla doküman analizi tekniğinden yararlanılmıştır. Araştırmanın veri toplama kaynă̆l ortaokullar ve imam hatip ortaokullar için hazırlanan 5, 6, 7 ve 8. sinıf matematik ders kitaplarından oluşmaktadır. Kitaplardan elde edilen veriler, betimsel analiz tekniğine uygun olarak analiz edilmiş ve eserlerde yer alan kök değerlerin sayfa numaraları verilerek sınıflandırılmıştır. Sonuç olarak incelenen matematik ders kitaplarında en sık rastlanan kök değerin sorumluluk (34 kez) en az rastlanan kök değerin ise dürüstlük (2) ve saygl (2) olduğu saptanmıştır. Bu sonuçtan hareketle incelenen matematik ders kitaplarının değerler eğitimi açısından kullanılabilecek düzeyde materyaller olduğu ancak kitaplardaki kök değerlerin dengeli bir dă̆ılımının olmadiğı söylenebilir. Çalışmanın sonuçlarına dayanarak ileriki zamanlarda ortaya konulacak olan matematik ders kitaplarında dengeli bir kök değer dă̆llımının gerçekleştirilmesi önerilmektedir.
\end{abstract}

Anahtar Kelimeler: Matematik dersi ögretim programı, matematik ders kitaplarl, kök değerler, nitel araştırma.

\begin{abstract}
:
It is possible for people to live in a healthy, peaceful and happy way in the society on the condition of the existence of the legal rules determined for that society as well as the values that the society has adopted, internalized and wants to pass on to future generations.Values are generally defined as generalized behavioral principles that set a certain standard in reaching a conclusion about the behavior or behavior patterns exhibited by people and that are formed by the emotional dependence of the people who make up the society.Educational institutions and the textbooks used in these institutions have a large share in the transfer of the values defined in this way to future generations.Because textbooks are seen as materials that help value education as well
\end{abstract}

\footnotetext{
${ }^{1}$ Milli Eğitim Bakanlığı, Türkiye. Orcid ID: 0000-0002-7154-6399

*Sorumlu Yazar (Corresponding Author): kilcantugba@gmail.com
} 
as mediating the transfer of the acquisitions in the curriculum. Within this context, the present study was done to examine the mathematics textbooks prepared for middle school and imam hatip secondary schools in terms of root values.The study designed in accordance with qualitative research method and document analysis technique was used for data collection.5th, 6th, 7th and 8th grade mathematics textbooks prepared for middle schools and imam hatip secondary schools form the data collection source of the study.The data obtained from the books were analyzed in accordance with the descriptive analysis technique and classified by giving the page numbers of the root values in the works. As a result, it was obtained that the most common root value in the analyzed mathematics textbooks was responsibility (34 times) and the least common root value was honesty (2) and respect (2).From this result, it can be said that the examined mathematics textbooks are materials that can be used in terms of values education however there is no balanced distribution of the root values in the books.Based on the results of the study, it is suggested to realize a balanced root value distribution in mathematics textbooks that will be revealed in the future.

Keywords: Mathematics course curriculum, mathematics textbooks, root values, qualitative research.

\section{GíRiş}

İnsanın tarih sahnesinde yerini almasından günümüze doğru, kendisinden başka kişilerle beraber yaşama istek ve zorunluluğunun arttığı bilinmektedir. Dünya nüfusunun artmasıyla oluşan bu durum insanların belli kurallara uyma gerekliliğini de beraberinde getirmiştir. $\mathrm{Bu}$ gerekliliğin yerine getirilmesi ulusal manada devletler tarafından ortaya konan yazılı kurallar çerçevesinde, uluslararası manada da çeşitli yasa koyucu oluşumlar aracılığıyla yapılmaktadır. Bunun yanında herhangi bir toplumun yazılı hale getirmediği, kanunlaştırmadığı ancak toplum tarafından onu oluşturan bireylerin birlikte sağlıklı, huzurlu, birbirlerinin hakkını gözeterek yaşamalarına imkân tanıyan ögelerin varlığını da göz ardı etmemek gerekir. Bu ögeler toplumlar ve onları oluşturan bireyler tarafından benimsenen değerlerdir.

Değerler var olan bir durumu bir başka duruma tercih etme ve değişme eğilimi (Erdem, 2003, s. 56); bir şeyin istenebilir ya da istenmez olduğuna yönelik inanç (Güngör, 1993, s. 18), insanlar tarafından sergilenen davranış ya da davranış kalıpları hakkında bir hüküm getirmede ve bu hüküm neticesinde belli bir yargıya ulaşmada bir standart ortaya atan ve bir oluşumu ya da topluluğu oluşturan kişilerin birbirleriyle duygusal açıdan bağlılıkları ile meydana gelmiş genelleştirilmiş davranış prensipleri; iyiyi-kötüyü, doğruyu yanlışı açığa çıkaran somut olmayan davranışsal ögeler (Aslan, 2007, s. 2; Esmer, 1999; Halstead ve Taylor, 2000; Theodorson \& Theodorson, 1979, s. 455; Özensel, 2003, s. 226; 2007, s. 744) olarak tanımlandığ1 gibi toplumların ait olduğu kültürünü oluşturan inançlar, fikirler ve normlar (Ülken, 1969, s. 73); toplumsal hayatta bireylerin beraberce önem atfettiği görgül içerikli olgular (Türk Sanayicileri ve İşadamları Derneği [TÜSİAD], 1991, s. 3) ve bireyin hayatında kıymet verilen, onun hayatına dokunan fikirler şeklinde (Doğanay, 2007, s. 258) de ifade edilmektedir. Yukarıda yer alan tanımlar genel manada değerlerin bireysel ve toplumsal tanımları ile ilişkili iken bu çerçeveyi genişletip daha da ileriye götüren bazı yazarlar (Bolay, 2007, s. 16; Özden, 2008, s. 37) değerlerin önemini "uğrunda fedakârlıklarda bulunulacak, hatta ölümün bile göze alınmaktan sakınılmayacağı" unsurlar olarak görmekte ve bunların bireylerin hayatlarını oluşturan temel prensiplerin belirlenmesinde vazgeçilmez olduğunu ifade etmektedirler. $\mathrm{Bu}$ vazgeçilmezlik olarak görme durumu insanların ve onların oluşturduğu toplumlar tarafından değerlere ne düzeyde sahip çıkılabileceğinin, onlar açısından ne denli önem arz ettiğinin göstergesi niteliğindedir.

Değerlerin gelecek kuşaklara aktarılması her dönemde tartışma konusu haline gelmiş ve toplumun hemen her kademesinden farklı bilim dalları tarafından merak ve uğraş konusu 
olmuştur. Günümüzde artık değerlerin ilk başta aileler sonrasında yakın ve uzak çevreleriyle (Aral, 2008, s. 9; Sayg1lı, 2015, s. 2; Tarhan, 2013, s. 24) ama genelde eğitim kurumları arac1lığ1 ile kazandırıldığı bilinmektedir. Değerler eğitimi eğitim kurumlarında değerlerin hem gizil olarak plansız hem de çeşitli yöntem ve tekniklerle planlı bir şekilde "öğrencileri belirlenen kurallar doğrultusunda disipline etmek, onların ahlakî gelişimine katkıda bulunmak ve karakterlerini olumlu yönde etkilemek" (Akbaş, 2008) amacıyla gerçekleştirilirken; kişinin ailesinde ve yakın/uzak çevresinde kazandırılmak istenen değerler için belli bir programın ve planın varlığından bahsedilemez.

Eğitim kurumlarında değerlerin planlı bir şekilde kazandırılmaya çalışılmasında öğretim programları önemli bir işleve sahiptir. Öğretim programları toplumun ihtiyaçları ve çağın gereklilikleri göz önünde bulundurularak hazırlanmaktadır. Hazırlanan bu programlarda bulunan değerler de yukarıda değinilen ihtiyaçlar ve gereklilikler doğrultusunda şekillenmektedir. Bu durum Schwartz ve Bilsky 'e göre değerlerin özelliğidir ve bu özellik onların değişime açık yapılar olduklarının, durağan olmadıklarının (Kuşdil ve Kağıtçıbaşı, 2000; Karakaya, 2007; Şimşir ve Dilmaç, 2020; Yalar, 2010) göstergesidir.

Eğitim kurumlarında okutulan derslerin öğretim programlarında yapılan son köklü değişiklik 2018 yılında gerçekleștirilmiștir. Bu değișiklikte şüphesiz çağın gereklilikleri ve toplumun ihtiyaçları gözetilmiştir. Değişiklikle ortaya çıkan programlarda "Değerlerimiz" adıyla bir başlik bulunmakta ve bu başlıkta tüm öğretim programlarında ortak olarak yer alan on kök değerden (adalet, dostluk, dürüstlük, öz denetim, sabır, saygı, sevgi, sorumluluk, vatanseverlik, yardımseverlik) bahsedilmektedir. On kök değerin kazandırılması aşamasında ise "değerler, öğrenme öğretme sürecinde hem kendi başlarına, hem ilişkili olduğu alt değerlerle ve hem de öteki kök değerlerle birlikte ele alınarak hayat bulacaktı" (MEB, 2018) denilerek kök değerin eğitimi ile ilgili hedeflenenler ortaya konmuştur.Programda değinilen bu hedeflere ulaşmada en önemli faktör öğretmenlerdir.Çünkü öğretmenlerin değerler eğitimi faaliyetlerini koordine etmesi, buna istekli olarak katılması değerlerin uygun zamanda kazandırılmasını ve değerler eğitiminin etkililiğini belirlemektedir.

Öğretmenler değerler eğitimi faaliyetini gerçekleştirirken bu faaliyete ilişkin var olan yaklaşımları kullanabilecekleri gibi derse ve konuya uygun olan farklı yöntem, teknik ve stratejiler ile değerler eğitimini konu edinen materyalden de yararlanabilirler (Australian Government Department of Education, Science and Traning, 2006, s. 56). Bu materyallerden birisi olarak da görülebilecek ders kitapları "Millî Eğitim Bakanlığına bağlı örgün ve yaygın eğitim kurumlarının haftalık ders çizelgelerinde yer alan derslerin öğretim programlarına göre hazırlanmış ve okutulması uygun bulunmuş eserlerdir" (MEB, 2019). Bu eserler toplumsal düzenin ve birlikteliğin korunması ve devam ettirilebilmesinde paya sahip olan değerlerin genç kuşaklara aktarılmasında ve değerlerin toplumda yeniden şekillenmesinde önemli bir rol oynamaktadırlar (Y1lar, 2016).

Literatürde farklı braşlarda yapılan değerler eğitimi konu alan çalışmalarının (Kurtoğlu, 2017; 2019; Kılcan ve Üçarkuş, 2018; Sönmez, 2014; 2019) yanında matematik ders kitaplarında değerler eğitimini konu alan çalışmaların (ortaokul matematik ders kitaplarındaki sosyal değerlerle ilgili Şahin ve Başgül, 2019 - 5. sınıf matematik ders kitabının değerler açısından incelenmesi ile ilgili Sayın, Orbay ve Altunay-Şam, 2019 - ilkokul matematik ders kitaplarının içerdiği değerler bakımından incelenmesi ile ilgili Uzunkol ve Karaca, 2019 - 7. sınıf ilköğretim matematik ders kitabının; görsel, duyuşsal ve akademik yönden incelenmesi ile ilgili Sefa, 2019) varlığ 1 bilinmektedir. Fakat bu yapılan çalışmaların matematik ders kitaplarında yer alan 
sosyal değerleri, sadece 5. sınıfta yer alan değerleri, ilkokul kademesinde okutulan matematik ders kitabındaki değerleri ve 7. sınıfa ait matematik ders kitabını hem duyuşsal hem de görsel ve akademik yönden incelediği görülmektedir. Ancak alan yazın incelendiğinde Türkiye'de değişen öğretim programlarından biri olan matematik dersi öğretim programında (ilkokul ve ortaokul 1, 2, 3, 4, 5, 6, 7 ve 8 . sinıflar) yer alan kök değerlerin ortaokul ve imam hatip ortaokulları için hazırlanmış matematik ders kitaplarında yer alma durumlarının incelendiği çalışmaya rastlanılmamıştır. Buradan hareketle mevcut çalışma 2018 matematik dersi öğretim programında yer alan kök değerlerin kazandırılmasında yararlanılabilecek materyallerden biri olan ortaokul ve imam hatip ortaokulları için hazırlanmış matematik ders kitaplarını, öğretim programında bahsi geçen on kök değer açısından incelemek amaciyla yapılmıştır. Gerçekleştirilen bu çalışmanın yeni matematik dersi öğretim programında yer alan kök değerlerin kazandırılmasında öğretmenlere yardımcı olacağı, daha sonra ortaokul ve imam hatip ortaokulları için hazırlanacak matematik ders kitaplarının kök değerler açısından içeriklerinin oluşturulmasına da katkı sunacağını düşünülmektedir.

\section{YÖNTEM}

Çalışmanın bu kısmında araştırmanın yöntemi, verilerin nasıl ve nereden toplandığı, nasıl analiz edildiği ile ilgili bilgilere yer verilmiştir.

Nitel araştırma bakış açısına dayanılarak oluşturulmuş bu araştırmada veriler doküman analizi tekniğine uygun olarak elde edilmiştir.Araştırılması planlanan olgular hakkında bilgiler sunan yazılı haldeki dokümanların analizini içeren ve yalnız başına da bir çalışmanın verisini oluşturabilecek olan (Punch, 2011; Yıldırım ve Şimşek, 2006) bu yöntem literatürde "belgesel gözlem", "mevcut kayıt ya da belgelerin veri kaynağı olarak sistemli incelenmesi", "belge taraması" ve "kitaplık araştırması" olarak da (Karasar, 2010) adlandırılmaktadır. Bu araştırma kapsamında veri toplama aracı olarak incelenen ortaokul ve imam hatip ortaokulları için hazırlanmış matematik ders kitapları doküman analizine kaynak teşkil eden verilerin elde edildiği belge olarak değerlendirilmektedir. Araştırmaya konu olan ortaokul ve imam hatip ortaokulları için hazırlanmış matematik ders kitaplarına ait bilgiler aşağıdaki tabloda verilmiştir.

Tablo 1. Ortaokul ve İmam Hatip Ortaokulları İçin Hazırlanmış Matematik Ders Kitaplarına Ait Bilgiler

\begin{tabular}{cccc}
\hline Kitaplar & Yayınevi & Yazarlar & Sayfa \\
\hline 5. Sinıf Matematik Ders Kitabı & Tuna & Orhan BİLEN & 306 \\
6. Sinıf Matematik Ders Kitabı & MEB & $\begin{array}{c}\text { Neziha ÇAĞLAYAN } \\
\text { Aybike DAĞISTAN } \\
\text { Betül KORKMAZ }\end{array}$ & 240 \\
& & Arzu KESKİN OĞAN & 297 \\
7. Sinıf Matematik Ders Kitabı & MEB & Soner OZTURK & 238 \\
8. Sinıf Matematik Ders Kitabı & MEB & Hadi BÖGE & Ramazan AKILLI \\
\hline
\end{tabular}




\section{Verilerin Toplanmast}

Araştırmanın verileri ortaokul ve imam hatip ortaokulları için hazırlanmış, tablo 1'de de yer alanmatematik ders kitaplarından elde edilmiştir. İncelenen kitaplardaki kök değerler ${ }^{1}$ (adalet, dostluk, dürüstlük, öz denetim, sabır, saygı, sevgi, sorumluluk, vatanseverlik, yardımseverlik) içeriği Milli Ĕ̆itim Bakanlığı [MEB] (2018) tarafından hazırlanmış, Matematik Dersi Öğretim Programında (İlkokul ve Ortaokul 1, 2, 3, 4, 5, 6, 7 ve 8. sinıflar) yer almaktadır. Kitaplardaki içeriğin kök değerler açısından incelenmesinde alıştırma ve ünite sonu soruları, konu ve ünite değerlendirme testleri ve "çözüm sende" başlığı altındaki sorular kapsam dışı bırakılmış, sadece kitaplardaki konu anlatımının yapıldığı, örneklendirmelerin verildiği kısımlar incelenmiştir. Sonuç olarak bu incelemeler neticesinde kök değerlerin ilgili kitaplardaki yer edinme durumları tespit edilerek araştırmanın bulguları oluşturulmuştur.

\section{Verilerin Analizi}

Çalışmada elde edilen verilerin analizi nitel bir veri analiz yöntemi olan betimsel analiz yaklaşımına uygun olarak gerçekleştirilmiştir. Betimsel analiz yöntemiyle elde edilen verilerin analizinde, toplanan veriler daha önceden var olan başlıklara ya da temalara göre yorumlanır veya özetlenir. Bu temalar araştırma sorularının başlığı olabileceği gibi nitel olarak gerçekleştirilen gözlem ve görüşmede kullanılan sorular ya da boyutlar kullanılarak da sunulabilir. $\mathrm{Bu}$ betimsel analiz yaklaşımındaaraştırmaya konu olan verilerden doğrudan alıntılara sıklıkla yer verilmektedir (Yıldırım ve Şimşek, 2006). Bu bağlamda yukarıda değinilen betimsel analiz sonucunda ulaşılan sonuçlar sunulmuş, incelenen kitapların içeriklerinden aynen alıntılar yapılarak bulgular kısmı oluşturulmuştur. Bunun yanında bulgular kısmında kitap içeriklerindeki kök değerlerin yer alma durumlarını gösterir frekans sayısı verilmiş hangi kitaplarda kaç adet kök değere rastlanıldığı tablolaştırılarak (Tablo 2) sunulmuştur. Kitap içeriğinde yer alan kök değerlere ilişkin tüm alıntıların sunulmasının okuyucu sıkacağı düşüncesinden hareketle her bir kök değere ilişkin sınırlı sayıda aynen alıntı yapılmıştır. Ayrıca kitap içeriklerinde az sayıda yer alan kök değerler ayrı ayrı başlıklar halinde değil de birlikte aynı başlık altında sunulmuştur.

\section{BULGULAR}

Bu kısımda incelenen matematik ders kitaplarında yer alan kök değerlerin sayısı ve kitaplarda yer alma durumları aynen alıntılanarak verilmektedir.

\footnotetext{
1 İncelenen matematik ders kitaplarındaki kök değerler belirlenirken hem o kök değerlerin doğrudan kitapta yer alması hem de o kök değerle ilişkili tutum ve davranışların örnekleri de ifade ediliyor olmasına dikkat edilmiştir.
} 
Tablo 2. Matematik Ders Kitaplarında Yer Alan Kök Değerler ve Yer Aldıkları Sayfalara Ait Numaralar

\begin{tabular}{|c|c|c|c|c|c|c|c|c|c|}
\hline \multirow{3}{*}{$\begin{array}{c}\text { Kök } \\
\text { Değerler }\end{array}$} & \multicolumn{8}{|c|}{ Sinıflar } & \multirow{3}{*}{$\frac{\Xi}{\frac{\pi}{0}}$} \\
\hline & \multicolumn{2}{|r|}{ 5. Sinıf } & \multicolumn{2}{|r|}{ 6. Sinıf } & \multicolumn{2}{|c|}{ 7. Sinif } & \multicolumn{2}{|c|}{ 8. Sinıf } & \\
\hline & f & S.no & f & s.no & f & S.no & f & S.no & \\
\hline Adalet & 3 & $45,62,63$ & 2 & 78,95 & 5 & $\begin{array}{c}86,90,126 \\
128,161\end{array}$ & 3 & $\begin{array}{c}21,101, \\
110\end{array}$ & 13 \\
\hline Dostluk & 5 & $\begin{array}{c}69,111,114 \\
148,151\end{array}$ & 1 & 197 & - & - & - & - & 6 \\
\hline Dürüstlük & 1 & 48 & - & - & - & - & 1 & 172 & 2 \\
\hline Öz denetim & 1 & 255 & 1 & 149 & 1 & 170 & 1 & 127 & 4 \\
\hline Sabır & 3 & $22,35,66$ & - & - & - & - & 1 & 27 & 4 \\
\hline Saygı & - & - & 1 & 18 & - & - & 1 & 67 & 2 \\
\hline Sevgi & 7 & $\begin{array}{c}69,111,114 \\
147,147 \\
148,151\end{array}$ & 12 & $\begin{array}{c}23,26,70, \\
72,79,95, \\
108,112,117, \\
130,185,223\end{array}$ & 4 & $\begin{array}{c}86,90, \\
103,161\end{array}$ & 6 & $\begin{array}{l}12,16,67 \\
67,80,206\end{array}$ & 29 \\
\hline Sorumluluk & 11 & $\begin{array}{c}19,29,58,59, \\
71,74,118, \\
196, \\
223,223,224\end{array}$ & 9 & $\begin{array}{c}26,29,81, \\
85,140,143, \\
187,214,229\end{array}$ & 9 & $\begin{array}{c}29,38,47 \\
103,153 \\
177,180 \\
236,270\end{array}$ & 5 & $\begin{array}{c}21,27,44 \\
61,72\end{array}$ & 34 \\
\hline Vatanseverlik & - & - & 3 & $26,29,187$ & 2 & 236,239 & - & - & 5 \\
\hline Yardımseverlik & 4 & $\begin{array}{c}10,76, \\
118,239\end{array}$ & 4 & $\begin{array}{l}41,106, \\
108,112\end{array}$ & 2 & 29,270 & 6 & $\begin{array}{l}17,49,61, \\
67,82,196\end{array}$ & 16 \\
\hline Toplam & 35 & & 33 & & 23 & & 24 & & \\
\hline
\end{tabular}

Tablo 2'ye bakıldığında 5. sınıf matematik ders kitabında toplam 35, 6. sinıfta 33, 7. sınıfta 23 ve 8. sınıfta 24 adet kök değerin olduğu görülmektedir. Dört ayrı matematik kitabına bir bütün olarak baktığımızda ise en fazla kendine yer bulan kök değerin sorumluluk (34 kez), kitaplarda en az yer verilen kök değerin ise dürüstlük (2 kez) ve saygı $(2 \mathrm{kez})$ olduğu tespit edilmiştir.

Aşağıda sınıf seviyeleri göz önünde bulundurularak her bir sınıf düzeyinde okutulmakta olan matematik ders kitabında yer alan kök değerlere ve bu değerlerin kitaplarda yer alma durumları verilmiștir.

\section{Beşinci sınıf matematik ders kitabında yer alan kök değerler}

Yukarıda yer alan tabloda beşinci sınıf matematik ders kitabındaki kök değerlerden en fazla paya sahip olanın 11 yerde söz edilen sorumluluk değeri olduğu görülmektedir. Bunun yanında beşinci sınıf matematik ders kitabında saygı ve vatanseverlik kök değerlerine hiç rastlanılmamıştır. Beşinci sınıf matematik ders kitabındaki kök değerlerin yer alma durumları aşağıdaki örnekler üzerinden tespit edilmiştir.

\section{Sorumluluk}

Beşinci sınıf matematik ders kitabında sorumluluk kök değerine yönelik ifadeler 11 farkı yerde bulunmaktadır. Bunlardan bazıları "Bir yerleşim bölgesinde geri dönüşüm kutularından 58349 adet şişe ve 28671 adet pil toplanmıştır. Buna göre geri dönüşüm kutularından toplanan şişelerin sayısı, pillerin sayısından kaç fazladır?" (s.29), "Kitap toplama kampanyasına katılan bir okulda toplanan kitapları 125 'ini 5 ve 6. siniflar, 41 'ini 7. siniflar ve kalan kitapları da 
8. sınıflar vermiştir. Buna göre 8. Sınıflar toplanan kitapların kaçta kaçını vermiştir?" (s.118) ve "Elif odasındaki kitaplı̆̆ düzenleyecektir. Elif'in odasındaki kitaplı̆̆ın raflarını, kitapları ve dosyaları birer doğru parçası modeli olarak kabul ederseniz bu nesnelerden hangileri birbirine paraleldir?" şeklindedir. Yukarıdaki alıntılamalarda yer alan bir yerleşim bölgesinde geri dönüşüm kutularından şişe ve pil toplanması, okuldaki öğrencilerin kitap toplama kampanyalarına katılmaları ve Elif adlı öğrencinin odasındaki kitaplığını düzenlemesi faaliyetleri sorumluluk kök değerinin kitapta yer aldığının ve bu değerin kazandırılmasında örnek olarak kullanılabileceğinin kanıtı sayılabilir.

\section{Sevgi}

Sevgi kök değerine yönelik ders kitabındaki ifadeler 7 farkı yerde bulunmaktadır. Bunlardan bazıları "Sema Öğretmen ve ögrencileri okullarındaki bahçeye 40 tanesi gül, 25 tanesi karanfil ve 35 tanesi papatya olmak üzere 100 tane çiçek fidesi dikmişlerdir" (s.147) ve "Huriye Hanım yaptığl çöreklerin 5'de 2 'sini komşularına, 5'de l'ini çocuk bahçesindeki çocuklara dağıtmıştır. Buna göre Huriye Hanım yaptı̆̆ı çöreklerin kaçta kaçını dağıtmıştır?” (s.111) şeklindedir. Bu örneklerde geçen öğretmen ve öğrencilerin çiçek fidesi dikmesi, öte yandan Huriye Hanım'ın komşularına ve çocuklara ikramlarda bulunması sevgi kök değerinin hem bitkilere hem de insanlara karşı olabileceğinin kitapta işlendiğinin ve bu durumun da sevgi kök değerinin kazandırılmasına fırsat tanıyacağının göstergesi sayılabilir.

\section{Dostluk}

Ders kitabında dostluk kök değerine yönelik ifadeler 5 farklı yerde tespit edilmiştir. Bunlardan bazıları “Ramazan Bayramı'nda 2 tepsi baklava yapan Gülay Hanım, bayramın ilk günü 1 tepsi, ikinci günü ise kalan 1 tepsinin 4'de 3 'ünü misafirlerine ikram etmiştir. Toplam kaç tepsi baklava yenmiştir?" (s.114) ve "Lütfiye Hanım yaptı̆̆l aşurelerin 5 'de 4 'ünü komşularına dağıtmıştır.5'de 4 kesrini ondalık gösterim ve yüzdelik olarak ifade edelim." (s.151) şeklindedir. Yukarıda yer alan örneklerdeki şahısların yaptıkları yiyeceklerden komşularına ve misafirlerine ikram etmeleri dostluğun bir göstergesidir. Dolaysıyla kitapta geçen bu örnekler dostluk kök değerinin örneklerle kitapta yer aldığının ve bu durumun da dostluk kök değerinin kazandırılmasında fayda sağlayacağının işareti olabilir.

\section{Yardimseverlik}

Ders kitabında bu kök değere ilişkin örnekler 4 farklı yerde görülmüştür. Bunlardan bazıları “Türkiye'de kış ortası su kuşu sayımları 2014 yılından itibaren Orman ve Su Işsleri Bakanlığ Doğa Koruma ve Millî Parklar Genel Müdürlüğünce koordine edilmektedir. 2018 verilerine göre doğrudan bakanlıkça belirlenen 153 alanda üniversiteler, sivil toplum kuruluşlarl ve gönüllülerin katılımıyla toplam 103 kuş türünden 1718675 su kuşu sayılmıştır..." (s.10) ve "1 224 kitap, her kutuda 24 kitap olacak şekilde kutulara konularak belirli okullara yardım için gönderilecektir. Her kutu için 12 TL kargo ücreti ödeneceğine göre toplam kaç TL kargo ücreti ödenir?" (s.76) şeklindedir. Yukarıda yer alan örneklerdeki ifadelerden su kuşlarının sayımına belli alanlardan gönüllülerin katılımı ve belli okullara yardım kutularının gönderilmesi faaliyeti karşılık beklenmeden yapılan işler olarak değerlendirildiğinden yardımseverlik kök değeriyle ilişkilendirilebilir. Bu örnekte yer verilenler yardımseverlik kök değerinin kitapta yer aldığının ve bu durumunda kök değerin kazandırılmasında fayda sağlayacağının kanıtı sayılabilir.

\section{Adalet}

Bu kök değere ilişkin 5. Sınıf ders kitabında 3 faklı ifade yer almaktadır. Bunlar "Bekir, 312 cevizi 11 arkadaşı ile eşit olarak paylaşacaktır. Her birine kaç ceviz düşer?" (s.45), "Pelin Öğretmen "Yayın ve İletişim Kulübü” nün hazırladığı 186 sayfalık dergiyi yazdırmak için dizgi 
bürosuna gider. Eşit sayıda sayfa yazmak koşuluyla 186 sayfalık dergiyi 5 çalışan yazacaktır. Her çalışanın kaç sayfa yazacă̆ını bulalım." (s.63) ve "Ayşe nine 5 elmayı 4 torununa eşit olarak paylaştırmak istiyor. Her toruna kaç adet elma düşeceğini bulalım." (s.62) şeklindedir. $\mathrm{Bu}$ ifadelerde geçen her eşitlik kelimesi ya da yapılması planlanan işlerin eşit şekilde, eşit kişilerce planlanması adalet kök değerinin ilgili kitapta işlendiğinin ve bu durumunda adalet kök değerinin kazandırılmasına imkân tanıyacağının göstergesi olabilir.

Sabir

Sabır kök değeri ile ilgili örneklere ilgili kitapta 3 farklı yerde rastlanılmıştır. Bunlardan biri kitabın 22. sayfasında yer alan görselin açıklamasında "Görsel 1 ve 2'de verilen Kahramanmaraş çocuk abalarının süslemelerinde çeşitli obje ve malzemelerin kullanıldı̆̆ görülmektedir. Bu malzemeler arasında tahta ve cam boncuk, tazı boncuğu, deniz kabuğu, metal paralar, iplik, saç örgüsü kolonlar, üçgen motifli farklı dokumalar, sutaşı vb. malzemeler yer almaktadır. Kullanılacak malzemeler özenle seçilmekte ve belli bir düzene göre teker teker el emeği ve sabır ile abalara işlenmektedir." şeklinde yer alırken diğeri ise "Berna, her hafta harçlığından 15 TL biriktirerek 8 hafta sonra tüm parasılla bir gitar almıştır." (s.66) şeklinde ifade edilmiştir. Hem görsellerde bahsedilen işlemelerin teker teker el emeği ve sabırla işlendiğine değinilmesi hem de ikinci örnekte yer alan kişinin amacına ulaşmak için her hafta harçlığından para biriktirmesi sabır kök değerinin kitapta yer aldığının ve bu örneklerin sabır kök değerinin eğitiminde kullanılabileceğinin kanıtı olarak gösterilebilir.

\section{Dürüstlük - Öz denetim}

Bu iki kök değere ilişkin 5. sınıf matematik ders kitabında birer adet örneğe rastlanılmıştır. Bunlar "Üzüm üreticisi olan Ahmet Bey, çevresinde dürüstlüğü ile taninan ve çok sevilen biridir. Ahmet Bey her yıl olduğu gibi öncelikle bağından topladığı üzümlerin çürük ve eziklerini ayırlyor. Daha sonra üzümleri her birinde 11 salkım olacak şekilde 29 kasaya dolduruyor. Buna göre Ahmet Bey’in toplam kaç salkım üzümü kasalara koyduğunu nasıl tahmin edebilirsiniz? (s.48)" ve "Zaman yönetimini etkili bir şekilde yapabiliyor olmak, erken yaşlarda kazanılan alışkanlıklardan biridir. Haftalık ve günlük program hazırlamak, zamanın daha verimli kullanılmasına yardımcı olur. Her hafta kendinize bir haftalık değerlendirme yapınız." (s.255) şeklindedir. Bu örneklerde geçen Ahmet adlı kişinin topladığ ürünlerin çürük ve eziklerini ayırması ve ayrıca bu gibi davranışlarından dolayı çevresinde dürüst olarak tanınması dürüstlük kök değerinin; öte yandan ikinci örnekte insanın kendisini değerlendirmesini ve kendine haftalık ve günlük programlar hazırlamasını tavsiye eden ifade ise öz denetim kök değerinin kitapta yer aldığının kanıtı sayılabilir. Dolaysıyla bu durum dürüstlük ve öz denetim kök değerlerinin kazandırılmasında ifade edilen örneklerin kullanılabileceğinin de göstergesi konumundadır.

\section{Altıncı sınıf matematik ders kitabında yer alan kök dĕgerler}

Tablo 2'de altıncı sınıf matematik ders kitabındaki kök değerlerden en fazla paya sahip olanın 9 yerde ifade edilen sevgi değeri olduğu görülmektedir. Bunun yanında altıncı sınıf matematik ders kitabında sabır ve dürüstlük kök değerlerine rastlanılmamıştır. Altıncı sınıf matematik ders kitabındaki kök değerlerin yer alma durumları aşağıdaki örnekler üzerinden tespit edilmiştir.

\section{Sevgi}

Bu kök değerin 6. sınıf matematik ders kitabında 12 farklı yerde ifade edildiği gözlemlenmiştir. Bunlardan bazıları "Ece, duvarda asılı olan dikdörtgen şeklindeki kendi fotoğrafinın yanına sınıf arkadaşlarıyla birlikte çektirdiği fotoğrafi asıyor." (s.23), "Ekim ayında Dünya Hayvanları Koruma Günü kapsamında gösterime girecek tiyatroda kazanılan para hayvanların 
beslenme ve barınma ihtiyaçları için kullanılacaktır. Gösterilecek tiyatroyu konu alan bir problem kurunuz ve kurduğunuz problemi çözünüz." (s.26) ve "Ela, her gün aynı miktarda yem ile tavukları beslemektedir. Ela'ya dedesi bir miktar yem almıştır. Ela, her gün aldıklarl yemin 8'de 1 'ini tavuklara vermiştir. Buna göre Ela'nın bir hafta boyunca tavuklara ne kadar yem verdiğini bulalım." (s.70) şeklinde ifade edilmiştir. Örneklerde bahsedilen hayvanların beslenme ve barınma ihtiyaçlarının karşılanması hayvan sevgisinin; Ece adlı kişinin duvara kendi fotoğrafının yanına arkadaşlarının da fotoğraflarını asması arkadaş sevgisinin ders kitabında işlendiğinin ve kitapta yer alan bu gibi örneklerin sevgi kök değerinin kazandırılmasında kullanılabileceğinin kanıtı sayılabilir.

\section{Sorumluluk}

Kitapta sorumluluk kök değerinin 9 farklı yerde ifadelendirildiği görülmüsstür. Bunlar "Atık yă̆lar, zehirli kimyasal yapısından dolayı bulunduğu ortamı kirletir ve ortamda yaşayan canlılara zarar verir. Evsel atıklardan kaynaklanan su kirliliğinin \%25'inin atık yağlardan kaynaklandığı belirtilmektedir. Lavaboya dökülen 1 litre atık yağ yaklaşık olarak 1 milyon litre suyu kirletmektedir. Atık yağlarını lavaboya atmayıp biriktiren Doğan, Yılmaz ve Kaya aileleri bu yağlarl geri dönüşüm tesislerine göndermeye karar vermişlerdir." (s.81) ve "Kanal ya da borular ile alınan suyun enerjisini türbinlerle elektrik enerjisine dönüştüren hidroelektrik santraller sayesinde çevre kirliliğine sebep olmadan enerji üretimi sağlanmaktadır." (s.143) şeklindedir. Örneklerde yer alan ailelerin atık yağları geri dönüşüme göndermeye karar vermeleri ile diğer örnekteki kanal ya da borular ile alınan suyun çevreye zarar vermemesi için hidroelektrik santrallerinde enerjiye dönüştürülmesi çevre sorumluluğu alt başlığında işlenmiştir. Bu durum sorumluluk kök değerine kitapta yer verildiğinin ve bu örneklerin kök değerlerin eğitiminde kullanılabileceğinin göstergesi olabilir.

\section{Yardımseverlik}

Yardımseverlik kök değerinin kitapta 4 farklı yerde ifadelendirildiği görülmüştür. Bunlar "Marangoz Fatih Usta, kitaplarını koyabilmesi için kızına $34,5 \mathrm{~cm}$ genişliğinde tek bölmeli kitaplık yapmıştır. Kızının her bir kitabının genişliği 1,5 cm olduğuna göre kitaplı̆̆ın en fazla kaç kitap alacă̆ını bulalım." (s.106) ve "Efe, tatilini geçirmek üzere 30 katlı bir otele gitmiş ve resepsiyon görevlisi tarafindan bilgilendirilmiştir. Resepsiyon görevlisi, misafirlere kolaylık sağlamak için 3 farklı özellikte asansörün olduğunu söylemiştir. Katlara çıkış ve iniş düzeni farklı olan bu asansörlerden birincisi her kata, ikincisi sadece 2 'nin katı olan katlara, üçüncü asansör ise sadece 3'ün katı olan katlara çıkıp inebilmektedir. Efe'nin hangi katta kalmayı seçerse üç asansörü de kullanabileceğini inceleyelim." (s.41) şeklindedir. Birinci örnekteki babanın kızına kitaplarını rahatça koyabilmesi için kitaplık yapması ve oteldeki görevlinin kişinin misafirlere kolaylık sağlaması yardımseverlik kök değerinin kitapta işlendiğinin ve bu örneklerin ilgili kök değerin kazandırılmasında işe yarayacağının ispatı sayılabilir.

\section{Vatanseverlik}

$\mathrm{Bu}$ kök değere ilişkin incelemeler sonunda ilgili kitapta 3 adet kök değere rastlanılmıştır. Bunların kitapta yer alama durumları "Tutum, Yatırım ve Türk Malları Haftası kapsamında sınıfında yapacă̆ l etkinlik için sergi açmayı planlayan sını öğretmeni, bulunduklarl yöreye ait ürünleri tanıtmak ve yerli malının kullanımını özendirmek için ögrencilerinden yöresel ürünler getirmelerini istiyor.” (s.26) ve “Türkiye'nin çölleşmesini önleme çalı̧̧maları kapsamında bir kampanya düzenlenecek ve her okula 12 tane fidan dikilecektir..." (s.29) şeklindedir. Örnekteki ifadelerden sınıftaki etkinlik kapsamında yerli mallarına, yöresel ürünlere özendirilmenin yapılması ve Türkiye'nin çölleşmemesi için fidan dikilmesinin planlanması vatanseverlik kök 
değerinin önemi kapsamında değerlendirilebilir. Bahsi geçen örneklerin kitapta yer alması ise öğrencilere bu kök değerin kazandırılmasında fayda sağlayabilir.

Adalet - Dostluk - Öz denetim - Sayg

Adalet, Dostluk, Öz denetim ve Saygı kök değerleri 6. sınıf matematik ders kitabında en az sayıda yer alan kök değerlerdir. Adalet değerine kitapta iki defa, diğerlerine ise birer defa rastlanılmıştır. Bu kök değerlerin kitapta yer alma durumları "Ayşe teyze, kuruttuğu kayısıları 3 çocuğuna eşit olarak paylaştırıyor. Kurutulan kayısıların ağırlığı 6 tam 3 bölü 4 kg olduğuna göre her bir çocuğa kaç kg kuru kayısı düştüğünü bulalım." (s.78), "Arkadaşınıza kıyafet hediye etmek ve alacağınız kıyafetin bedeninin arkadaşınıza uygun olmasını istiyorsunuz. Bunun için arkadaşınızın vücut ölçülerini gözünüzün önüne getirip bir tahminde bulunursunuz. Tahmin yürütmek matematiği kullanmak demektir. (s.197), "Uzmanlara göre verimli ders çalışma, belirli bir amaç doğrultusunda planlı ve programlı olmalıdır. Derslerde başarılı olabilmenin ilk şartı amaçların iyi belirlenmesidir. Ayrıca motivasyon, konu tekrarı, zamanın iyi kullanılması, etkin dinleme gibi verimli ders çalışma yöntemlerinin de bilinmesi gerekmektedir." (s.149) ve "Sağlık hizmeti veren kuruluşlarda bazı bireylerin hizmetlerden öncelikli olarak yararlanma hakkı vardır. Muayene olmak için sıra bekleyen hamile, engelli, 65 yaş üstü ve 7 yaş altı bireylerden birinci öncelik engellilerde, ikinci öncelik hamilelerde, üçüncü öncelik 65 yaş üstü bireylerde, dördüncü öncelik ise 7 yaş altı bireylerdedir." (s.18) şeklindedir. Örnekte yer alan Ayşe adlı kişinin kuruttuğu ürünleri çocuklarına eşit olarak paylaştırması adaletin, bir kişinin arkadaşına kıyafet almaya karar vermesi aradaki dostluğun, uzmanlara göre bir kişinin verimli ders çalışmak için motivasyon, zamanın iyi kullanılması, planlı ve programlı olmak gibi etmenler öz denetimin ve muayene sirası bekleyenlerden belli bireylerin öncelikli olduğuna yönelik bilgilendirmelerde onlara sayg1 gösterilmesini akıllara getirdiği için saygı kök değerinin ders kitabında yer aldığının kanıtıdır. Bu durum da bu kök değerlerin eğitiminde ilgili örneklerden yararlanılabileceğini göstermektedir.

\section{Yedinci sınıf matematik ders kitabında yer alan kök değerler}

Tablo 2'de yedinci sınıf matematik ders kitabındaki kök değerlerden en fazla paya sahip olanın 9 yerde ifade edilen sorumluluk kök değeri olduğu tespit edilmiştir. Bunun yanında yedinci sınıf matematik ders kitabında dostluk, saygı, sabır ve dürüstlük kök değerlerine rastlanılmamıştır. Yedinci sınıf matematik ders kitabındaki kök değerlerin yer alma durumları aşağıdaki örnekler üzerinden tespit edilmiştir.

\section{Sorumluluk}

Sorumluluk kök değerine ilişkin incelemeler sonunda ilgili kitapta 9 adet ifadeye rastlanılmıştır.Bunlardan bazılarının kitapta yer alama durumları "Menenjit, zatürre, kızamık gibi hastalıklar bakteriler yoluyla bulaşan hastalıklardır.Bu tür bakteriyel hastalıklar, bağışıklık sistemleri zayıf olduğu için daha çok çocuklarda görülür.Bu hastalıkların çoğu bulaşıcıdır.Bakterilerden korunmak için eller iyi yıkanmalı, kişisel temizliğe dikkat edilmelidir.Öksürme ve aksırma sırasında koruyucu önlemler alınmalıdır."(s.47)ve "Küresel ısınma; atmosfere salınan gazların neden olduğu düşünülen sera etkisinin sonucunda, Dünya üzerinde yıl boyunca kara, deniz ve havada ölçülen ortalama sıcaklıklarda görülen artıştır. Küresel ısınma sonucunda kutuplardaki buzullar erimekte, deniz suyu seviyesi yükselmekte ve kıyı kesimlerde toprak kayıpları artmaktadır. Bunun yanında bazı bölgelerde kasırgalar, seller ve su taşkınları yaşanırken bazı bölgelerde de şiddetli kuraklıklar yaşanmaktadır. Bu dünya hepimizin. Yaşamımızda alacağımı basit önlemlerle küresel ısınmayı azaltabiliriz." (s.153) şeklindedir. Örnekte yer alan ifadelere bakıldığında belirtilen hastalıklara yakalanmamak ve küresel ısınmanın önüne geçmek için alınacak önlemlerden söz edilmesi sorumluluk kök 
değerinin kitapta işlendiğinin ve bu değerin öğrencilere kazandırılmasında kitapta yer alan örneklerin kullanılabileceğinin kanıtıdır.

\section{Adalet}

Adalet kök değeri ilgili kitapta 5 yerde yer almaktadır.Bunlardan bazıları "Bir futbol maçının biletleri; kale arkası 15 TL, açık tribün 20 TL ve kapalı tribün 35 TL olarak satılmıştır.3000 biletin satıldi ğ bu futbol maçında biletlerin 2 bölü 3' ü 20 TL'lik biletlerdir.Bu futbol maçında açık tribün için kaç bilet satıldığını bulunuz."(s.86)ve "25 kişilik bir sınıf, bir araya gelerek doğum gününde Meliha'ya hediye almaya karar verirler. Masraflar hesaplandiğında kişi başına 12 TL düşer. Ancak 5 kişi hediyeye katılmaktan vazgeçer. Bu durumda aynı hediyeyi almak için kişi başına düşen para miktarını hesaplayalım." (s.161) şeklindedir. Örneklerde yer alan ifadelerde futbol maçının bilet fiyatlarının oyunun nerede izleneceğine bağlı olarak değişmesi ve ona göre izleyicilerden ücret alınması ile diğer örnekte doğum gününde hediye almak için bir araya gelen arkadaşların hediye için eşit ücret ödemesi gerektiği anlayışı ilgili kitapta adalet kök değerinin yer aldığının ve bu değerin öğrencilere kazandırılmasında kullanılabilecek örnekler olduğunun kanıtı sayılabilir.

\section{Sevgi}

Bu kök değerin kitapta 4 farklı yerde ifade edildiği saptanmıştır. Bunlardan bazıları "Semra için bir doğum günü partisi düzenleyen annesi, eş büyüklükte 5 pasta sipariş eder. Doğum gününe Semra'nın 16 arkadaşını davet eden annesi, her bir arkadaşının çeyrek pasta yiyebileceğini düşünür." (s.90) ve “Ahmet bir pastanın 1 bölü 4'ünü yemiştir. Kalan pastanın 2 bölü 3 'ünü kardeşine verecektir. Ahmet'in kardeşine vereceği miktarın, pastanın kaçta kaçı olacağını bulalım." (s.86) şeklindedir. Örneklerde yer alan ifadelerde bir annenin çocuğu için doğum günü partisi düzenlemesi ve bir kişinin yemesi için kardeşine pasta vermesi sevgi kök değerinin ilgili kitapta yer aldığının ve bu kök değerin eğitiminde ilgili örneklerin kullanılabileceğinin göstergesidir.

Vatanseverlik - Yardimseverlik - Öz denetim

Vatanseverlik, Yardımseverlik ve Öz denetim kök değerleri 7. sınıf matematik ders kitabında en az sayıda yer alan kök değerlerdir. Vatanseverlik ve Yardımseverlik kök değerlerine ilgili kitapta ikişer defa, öz denetime ise bir defa rastlanılmıştır. Bu kök değerlerin kitapta yer alma durumları 'Gökhan'ın Merve ve Harun'a toplam 10 TL borcu vardır. Gökhan'in Merve'ye olan borcu 8 TL ise Harun'a olan borcunun matematiksel olarak nasıl ifade edildiğini bulalım.”(s.29), “Ülkemizde kanalizasyon kapaklarının neredeyse tümü daire şeklindedir.Bunun en önemli nedeni, bu kapakların herhangi bir sebeple açıldı̆̆ında rögara düşme olasılıklarının olmayışıdır.Kapaklar dikdörtgen veya kare olsalardı köşegen ekseninde rögarın içine düşebilirlerdi.Daire şeklindeki rögar kapakları, şekilleri yönüyle en az malzeme kullanılarak üretildiklerinden ekonomiktirler."(s.239)ve “Obezite, vücutta sağlĭgl bozacak ölçüde aşırı ve anormal yă̆ birikmesi sonucu meydana gelen bir hastalıktır. Bu hastalı̆̆ yaşayan kişiler de obez olarak kabul edilmektedir. Dünyada giderek yayginlaşan obezite, yaşam kalitesini ve süresini olumsuz yönde etkilemektedir. Hareketsiz yaşam, düzensiz beslenme ve özellikle hazır yiyecek kültürünün yaygınlaşması, obezitenin artmasında önemli bir etkendir. Obez olmak istemiyorsan daha hareketli yaşa, sağllklı ve dengeli beslen!” (s.170) şeklindedir. İfadelerde Merve ve Harun adlı kişilerin ihtiyacı olan arkadaşlarına borç para vermeleri yardımseverlik kök değerinin, Rögar kapaklarının daire şeklinde üretilmesinin daha ekonomik oluşu vatanseverlik kök değerinin ve obez olmak istemeyen insanların davranışlarını kontrol etmeleri gerektiğine yönelik ifadeler ise öz denetim kök değerinin ilgili kitap yer 
aldığının ve bu durumunda kök değerlerin eğitiminde öğrencilere örnek olarak sunulabileceğinin kanıtı sayılabilir.

\section{Sekizinci sınıf matematik ders kitabında yer alan kök dĕgerler}

Tablo 2'de sekizinci sınıf matematik ders kitabındaki kök değerlerden en fazla paya sahip olanların kitapta 6'şar defa yer verilen sevgi ve yardımseverlik kök değerleri olduğu görülmüştür. Bunun yanında sekizinci sınıf matematik ders kitabında dostluk ve vatanseverlik kök değerlerine rastlanılmamıştır. Sekizinci sınıf matematik ders kitabındaki kök değerlerin yer alma durumları aşağıdaki örnekler üzerinden tespit edilmiştir.

\section{Sevgi}

Bu kök değerin kitapta 6 farklı yerde ifade edildiği görülmüştür. Bunlardan bazıları "16 yaşındaki Hayri ve kendisinden 6 yaş küçük kardeşi Selin, her hafta sonu Halime ninelerini ziyaret ederler." (s.16) ve "Elif, küçük kardeşi Ahmet'e 23 Nisan Ulusal Egemenlik ve Çocuk Bayramı'nda hediye vermiştir. Hediyeyi dik dairesel silindir şeklinde bir kutuya yerleştirip kutunun dışını da simli bir kâğıt ile kaplamıştır. Elif simli kâğıdın alanını hesaplarken hangi bilgilere ihtiyaç duymuştur, düşününüz ve açıklayınız." (s.206) şeklindedir. Örneklerde yer alan ifadelerdeki kardeşlerin, ninelerini her hafta sonu ziyaret etmeleri ve bir ablanın kardeşine 23 Nisan Ulusal Egemenlik ve Çocuk Bayramı münasebetiyle hediye vermesi sevgi kök değerinin ilgili kitapta işlendiğinin ve bu durumun da öğrencilere sevgi kök değerinin eğitiminde kullanılabileceğinin kanıtı sayılabilir.

\section{Yardımseverlik}

Yardımseverlik kök değeri sekizinci sınıf matematik ders kitabında 6 farklı yerde dile getirilmiştir. Bunlar "Aydın Market, Ramazan ayında mahallesindeki yoksul ailelere yardım etmek için $100 \mathrm{~kg}$ bulgur ve $80 \mathrm{~kg}$ mercimek ayırmıştır. Bulgur ve mercimekleri eşit kütlede ve birbirine karıştırmadan paketlemek için en az kaç poşete ihtiyaç vardır? Düşününüz ve açıklayınız."(s.17)ve "3 Aralık Dünya Engelliler Günü nedeniyle engelli çocuklara tekerlekli sandalye almak için yardım amaçlı bir resim sergisi düzenlenmek isteniyor..." (s.49) şeklinde ifade edilmiştir.Bu ifadelerde geçen market sahibinin yoksu ailelere yardım etmesi ve 3 Aralık Dünya Engelliler Günü münasebetiyle engelli çocuklara tekerlekli sandalye yardımında bulunulması yardımseverlik kök değerinin ilgili kitapta yer aldığının ve kök değerler eğitiminde kullanılabileceğinin göstergesidir.

\section{Sorumluluk}

Bu kök değer ders kitabında 5 farklı yerde dile getirilmiştir. Bunlar "Trafik işaretleri, insanların güvenli bir şekilde yaya olarak veya araçları ile seyahat etmeleri için kullanılmaktadır. Güvenliğimiz için trafik işaretlerine dikkat etmeli ve trafik kurallarına uymalıyız." (s.44) ve "Evinin ihtiyaçlarını düzenli olarak karşılayan sorumluluk sahibi bir baba, ailesinin bir yılda tüketeceği 50-kilogram mercimeğin ve 98-kilogram bulgurun erken bozulmasını önlemek için birbirine karışmayacak şekilde eşit kütlede paketlemek istemektedir. Bu iş için en az kaç adet pakete ihtiyaç vardır?" (s.21) şeklindedir. Örneklerdeki ifadelerden trafik işaretlerine uymamız gerektiğinin altının çizilmesi ve bir babanın evinin ihtiyaçlarını düzenli olarak karşılaması aynı zamanda da o ihtiyaçların bozulup çürümemesi için tedbirler alması sorumluluk kök değerinin kitapta işlendiğinin göstergesidir. Bu durum da kök değerlerin eğitiminde belirtilen örneklerin kullanılabileceğinin kanıtı olarak gösterilebilir. 


\section{Adalet}

Adalet kök değeri sekizinci sınıf matematik ders kitabında 3 farklı yerde dile getirilmiştir. Bunlar "Kâmil amca, bahçesinden topladı ̆̆ $(6 x+12) \mathrm{kg}$ portakalı altı çocuğuna eşit bir şekilde paylaştırmak istemektedir." (s.101) ve “...toprak sahipleri, sahip olduklart toprak miktarları kadar devlete vergi ödemekteydiler. Bu nedenle her taşkından sonra devletin görevlendirdiğ $i$ matematikçiler, bu arazilere giderek ölçüm yapıyorlar ve arazilerin sınırlarını belirliyorlardı" (s.110) şeklindedir. Örneklerde yer alan ifadelerde kişinin portakalı çocuklarına eşit oranda paylaştırmak istemesi ve diğer örnekte yer alan toprak sahiplerinin sahip oldukları toprak miktarı kadar devlete vergi ödemeleri durumu adalet kök değerinin kitapta yer aldığının ve bu kök değerin eğitiminde kullanılabileceğinin göstergesi sayılabilir.

\section{Dürüstlük - Öz denetim - Sabır - Saygl}

Dürüstlük, Öz denetim, Sabır ve Saygı kök değerlerinin sekizinci sınıf ders kitabında birer defa yer bulduğu tespit edilmiştir. Bunlar "Dürüst bir çocuk olan Eren, çok sevdiği büyükbabasına beraber çektirdikleri fotoğrafı odasına asacağına dair söz vermiştir. Fotoğrafı odasının uygun bir yerine asmak için yukarlda verilen birbirine benzer dikdörtgen çerçevelerden II. çerçevenin verilmeyen kenarının uzunluğunu bulması için Eren'e yardımcı olalım." (s.172), "90 kg olan Nazım Bey, kilosunun fazla olduğunu düşünerek diyetisyene gidiyor. Diyetisyen, yaptı̆̆ tahliller sonucunda Nazım Bey'in ideal kilosunun $75 \mathrm{~kg}$ olduğunu söylüyor ve Nazım Bey'in bu kiloya gelebilmesi için her ay $3 \mathrm{~kg}$ verebileceği şekilde bir diyet programı hazırliyor." (s.127), "Asşı Veysel hayranı olan Kürşat, bir bağlama alabilmek için her hafta kumbarasına düzenli olarak $3^{4}$ lira para atmaktadır. Kürşat $3^{2}$ hafta sonra kumbarasında biriken para ile bir bağlama alabilmiştir." (s.27) ve "Bir okulda "18 Mart Çanakkale Zaferi ve Şehitleri Anma Günü” kapsamında gerçekleştirilen geziye katılan sınıfların ögrenci sayılarl yandaki grafikte gösterilmiştir." (s.67) şeklindedir. Örneklerde ifade edilen bir çocuğun dedesine beraber çektirdikleri fotoğrafı odasına asacağına söz vermesi dürüstlük kök değerinin; ideal kilosu 75 kilo olan birisinin zayıflamak için belli bir sıklıkta davranışlarını kontrol etmesi gerektiğine yönelik ifadeler öz denetim kök değerinin; bağlama alabilmek için kumbarasında para biriktiren çocuğun davranışı sabır ve bir okuldaki çocukların 18 Mart Çanakkale Zaferi ve Şehitleri Anma Günü münasebetiyle geziye katılmaları saygı kök değerlerinin kitapta yer aldığının göstergesidir. $\mathrm{Bu}$ durum aynı zamanda kitapta yer alan örneklerin bu değerlerin kazandırılmasında fayda sağlayacağının da göstergesidir.

\section{TARTIŞMA, SONUÇ VE ÖNERILER}

Ortaokul ve imam hatip ortaokulu matematik ders kitaplarının matematik dersi öğretim programında (ilkokul ve ortaokul 1, 2, 3, 4, 5, 6, 7 ve 8. sinıflar), (2018) yer alan kök değerler açısından incelendiği bu çalışmada on kök değerin tamamının belli sayılarda kitaplarda yer aldığı görülmüştür. Dört farklı matematik kitabında 34 farklı yerde sorumluluk değeri yer almaktayken dürüstlük ve saygı değerlerine yalnızca 2'şer yerde rastlanılmıştır.

Kitaplarda en çok rastlanılan sorumluluk kök değerinin beşinci sınıf kitabında diğer sınıf düzeylerine ait kitaplara nazaran daha fazla işlendiği görülmüştür. Bu bulgu Uzunkol ve Karaca (2017) tarafından yapılan çalışmanın sonuçlarıyla farklılaşırken, Şahin ve Başgül (2019) tarafından yapılan çalışmanın sonuçlarıyla örtüşmektedir. Uzunkol ve Karaca'nın yaptığı 3. ve 4. sınıf matematik kitaplarında yer alan değerlerin incelendiği çalışmada sorumluluk en az rastlanan değerlerden biri olmuştur. Öte yandan Şahin ve Başgül yaptıkları çalışmada ise ortaokul matematik ders kitaplarında yer alan sosyal değerleri incelemiş ve kitaplarda işlenen ez fazla değerin sorumluluk olduğunu tespit etmişlerdir. Mevcut araştırmada sorumluluk kök 
değerinin işlendiği örneklerin genelde çevreye ve doğaya karşı olan sorumlulukları kapsadığı bunun yanında bireylerin başkalarına yani ailelerine olan sorumluluklarına çok fazla yer verilmediği hatta bireyin geleceğine ilişkin planlamalar yapmada alacağı sorumluluğu işleyen yani kendisine karşı sorumluluğunu ifade eden söylemlere kitaplarda yer verilmediği tespit edilmiştir. Öte yandan sorumluluk kök değerinin kitaplarda fazlaca yer alması olumlu bir durumdur. Çünkü bireylere küçük yaşlardan itibaren onları sıkmayacak ve altından kalkabilecekleri biçimde sorumluluklar vermek ve bunları takip etmek onların sorumluluklarında (Beil, 2003; Tepecik, 2008) kendilerine olan güven duygusunun gelişimde önemli bir paya sahiptir.

Kitaplarda işlenme fazlalığı açısından ikinci paya sahip olan sevgi kök değeridir. Bu kök değeri konu alan ifadeler genelde çiçek ve hayvan sevgisi ile insan sevgisi (kardeş, nine-dede, komşu, çocuk) temeline dayanmaktadır. İncelenen kitaplarda sevgi kök değerine ilişkin ifadelere fazlaca rastlamak Şahin ve Başgül (2019) tarafından yapılan çalışmanın sonuçlarıyla örtüşürken Sayın, Orbay ve Altunay-Şam, (2019) tarafindan yapılan çalışmanın sonuçlarıyla farklılaşmaktadır. Çünkü Şahin ve Başgül (2019) yaptıkları araştırmada sevgi değerinin inceledikleri eserde fazlaca yer alan değerlerden biri olduğundan bahsederlerken Sayın, Orbay ve Altunay-Şam (2019) inceledikleri eserlerde sevgi değerine fazlaca rastlamamışlardır.

Yardımseverlik kök değeri de kitapta fazla rastlanılan değerlerden biri olarak görülebilir. $\mathrm{Bu}$ durum Şahin ve Başgül (2019) ve Uzunkol ve Karaca (2017) tarafından yapılan çalışmaların sonuçlarıyla farklılaşırken Sayın, Orbay ve Altunay-Şam, (2019) tarafından yapılan çalışmanın sonucuyla örtüşmektedir. Mevcut çalışmada yardımseverlik kök değeri genelde ihtiyaç sahiplerine yardım etme şeklinde işlenmiştir.

Adalet kök değeri de yardımseverlik kök değerine yakın bir şekilde kitaplarda ifadelendirilmiştir.Bu durum Sayın, Orbay ve Altunay-Şam (2019) tarafından yapılan çalışmanın sonuçlarıyla kısmen örtüşmektedir.İlgili çalışmada adalet değeri kitaplarda tespit edilen en fazla değerdir.Mevcut çalışmada tespit edilen adalet kök değeri kitaplarda genelde bir kişinin paylaştırmak istediği bir şeyi eşit olarak paylaştırması ya da ortak yapılacak bir işte eşit davranma ve yahut eşit ücret ödeme şeklinde örneklendirilmiştir. Bunun yanında bazı ifadelerde (“...toprak sahipleri, sahip oldukları toprak miktarları kadar devlete vergi ödemekteydiler", "Bir futbol maçının biletleri; kale arkası 15 TL, açık tribün 20 TL ve kapalı tribün 35 TL olarak satılmıştır.") insanların ödedikleri ücret kadar karşılık almaları ya da sahip olunana oranla vergi vermeleri evrensel manada adalet anlayışının kitaplara yansıdığının kanıtıdır.

Dostluk kök değeri ise kitaplarda az sayıda denilebilecek kadar bulunan kök değerlerdendir. Sayın, Orbay ve Altunay-Şam (2019) tarafından yapılan çalışmada da dostluk değerinin 5. sınıf matematik ders kitabında çok az sayıda bulunması bu araştırmanın sonuçlarını kısmen destekler mahiyettedir. Kitaplarda dostlukla ilgili ifadelerin genelde arkadaşa, komşuya, misafire bir şeyler ikram etmek, onlara hediye almak şeklinde işlenmesi aslında misafirperverlik göstermenin ve arkadaş sevgisinin dostluk değeri altında toplandığının da kanıtı sayılabilir.

Vatanseverlik kök değeri de tıpkı dostluk kök değeri gibi kitaplarda az rastlanan değerlerdendir. Bu durum Sayın, Orbay ve Altunay-Şam (2019) tarafından yapılan çalışmanın sonuçlarıyla örtüşürken Uzunkol ve Karaca (2017) tarafından yapılan çalışmaların sonuçlarıyla farklılaşmaktadır. Uzunkol ve Karaca'nın çalışmasında vatanseverlik değeri hem 3. sınıf hem de 4. sınıf kitaplarında fazlaca rastlanan değerlerdendir. Mevcut çalışmada vatanseverlik kök değeri yerli malını koruma, ülkenin ihtiyacı için fidan dikme ve sokaklarda kullanılacak 
malzemenin hem işlevselini hem de ekonomik olanını tercih etme olarak işlenmiştir. Bu kök değerin kitaplarda bu şekilde yer alması vatanseverliğin aynı zamanda doğup büyünülen topraklara özlem duyma ve vatan için büyük fedakârlıklarda bulunma (Kılcan, 2013) gibi boyutlarının ihmal edildiğinin göstergesi sayılabilir.

Öz denetim kök değeri de kitaplarda az görülen kök değerlerdendir. Bu durum Sayın, Orbay ve Altunay-Şam (2019) ve Uzunkol ve Karaca (2017) tarafından yapılan çalışmaların sonuçlarıyla farklılaşmaktadır. İlgili çalışmalarda öz denetim değeri bu çalışmaya göre daha fazla tespit edilen değerler arasındadır. $\mathrm{Bu}$ kök değerin kitaplara yansımaları zaman yönetiminin kazanılması ve buna bağlı olarak etkili/verimli çalışmak, fazla kilo alıp hastalanmamak için kendini kontrol etmek gibi ifadelerle işlenmiştir.

Sabır kök değeri ise yine kitaplarda az rastlanan kök değerlerdendir. Sayın, Orbay ve AltunayŞam'ın (2019) çalışmalarında bu değere hiç rastlamamaları kısmen bu çalışmanın sonuçlarıyla örtüşmektedir.Bu kök değer kitaplarda bir objenin yapılması aşamasında acele etmeden emek sarf etmek ve bireylerin almak istedikleri bir ürün için acele etmeden para biriktirmeleri üzerinden işlenmiştir.Eserde sabır kök değerinin bu şekilde yer bulması onun evrensel manada bir değer olarak gösterilmeye çalışıldığının kanıtı sayılabilir.Çünkü sabır, başarılmak istenen bir şey için ortaya çıkabilecek zorluklar karşısında acele etmeden ona direnme, amaçtan vazgeçmeme olarak ifade edilmektedir (Demirci, 2002).

Dürüstlük ve Saygı kök değerleri ise incelenen kitaplarda en az sayıda ifadelendirilen kök değerlerdir. Saygı kök değerinin kitaplarda en az sayıda yer alması Uzunkol ve Karaca (2017), Şahin ve Başgül (2019) ve Sayın, Orbay ve Altunay-Şam'ın (2019) tarafından yapılan çalışmanın sonuçlarıyla da örtüşmektedir. Saygı kök değeri mevcut çalışmada sağlık kuruluşunda muayene olmak için öncelikli olan kişilere hak tanımak ve önemli gün ve haftalarda duyarlı davranmak temelinde işlenmiştir. Öte yandan dürüstlük kök değerinin ise bu çalışmada en az sayıda yer verilen kök değerlerden biri olması yine Sayın, Orbay ve AltunayŞam'ın (2019) tarafından yapılan çalışmanın sonuçlarıyla örtüşmektedir. Mevcut çalışmada dürüstlük bir çiftçinin ürünlerinden bozuk olanlarını satmaması ve bir kişinin verdiği sözünü yerine getirmek istemesini temel almaktadır. Kitaplarda geçen ifadelerde dürüstlügün bu şekilde yer alması onun evrensel açısından önemini ortaya koymaktadır. Çünkü dürüstlük başka şekilde görünme çabası içinde olmayan, gerçekleri saklamayan, doğruluktan ayrılmayan ve erdemli insanların tanımlanmasında kullanılan bir değerdir (Mindivanlı, Küçük ve Aktaş, 2012; Paleg, 1998).

Yukarıda ifade edildiği üzere 2018 yılında yenilenen matematik dersi öğretim programında kök değerlere yer verilmiştir. Bu kök değerlerin öğrencilere kazandırılmasında ortaokul ve imam hatip ortaokulları matematik ders kitaplarında yer alan ifadelerden yararlanmak bu kök değerlerin eğitimini kolaylaştırabilir. Ancak başta kök değerler daha sonra da sınıflar açısından dengeli bir dağılımın ders kitaplarında yapılmaması kök değerlerin öğrencilere kazandırılması faaliyetini sekteye uğratabilir. O bakımından sonraki dönemlerde gerçekleştirilecek matematik ders kitabı hazırlama çalışmalarda yukarıda değinilen hem kök değer hem de sınıflar bazında dengeli bir dağılım yapılması önerilmektedir.

\section{KAYNAKÇA}

Akbaş, O. (2008). Değer eğitimi akımlarına genel bir bakış. Değerler Ĕ̆itimi Dergisi, 6(10), 9-27. 


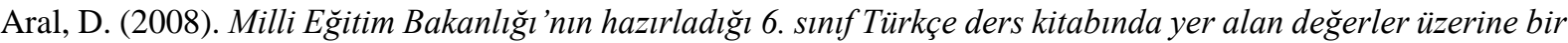
araştırma. [Yayınlanmamış Yüksek Lisans Tezi. Abant İzzet Baysal Üniversitesi].

Aslan, R. (2007). Öğretmen görüşlerine göre ilköğretim birinci basamaktaki ögrencilerin temel bilgi, beceri ve değerleri kazanma düzeyleri. [Yayınlanmamış Yüksek Lisans Tezi, Anadolu Üniversitesi].

Australian Government Department of Education, Science and Training. (2006). Implementing the national framework for values education in australian schools, final report. (online version). http://www.valueseducation.edu.au/verve/_resources/VEGPS1_FINAL_REPORT_081106.pdf

Beil, B. (2003). İyi çocuk, zor çocuk 'doğru davranışlar çocuklara nasıl kazandırılır?' (Çev. C. Yorulmaz). Arkadaş.

Bolay, S. H. (2007). Değerlerimiz ve günlük hayat. Değerler Ĕ̆itimi Merkezi Dergisi, 1(1), 12-19.

Demirci, M. (2002). Kur’an-1 Kerim ışığında sabır kavramı. Erciyes Üniversitesi Sosyal Bilimler Enstitüsü Dergisi, $1(12), 263-285$.

Doğanay, A. (2007). Değerler eğitimi. C. Öztürk (Ed.), Hayat bilgisi ve sosyal bilgiler öğretimi yapılandırmacı bir yaklaşım. (3. Bask1). Pegem A. ss.255-286.

Erdem, A. R. (2003). Üniversite kültüründe önemli bir unsur: Değerler. Değerler Ĕ̆itimi Dergisi, 1(4), 55-72.

Esmer, Y. (1999). Devrim, evrim, statüko: Türkiye'de sosyal, siyasal, ekonomik değerler. TESEV. https://www.tesev.org.tr/wp-content/uploads/rapor_devrim_evrim_statuko.pdf.

Güngör, E. (1993). Değerler psikolojisi. Hollanda Türk Akademisyenler Birliği Vakfı.

Halstead, J. M. \& Taylor, M. J. (2000). Learning and teaching about values: A review of recent research. Cambridge Journal of Education, 30(2).169-202.

Karakaya, T. (2007). Küreselleşme ve Avrupa birliği sürecinde etik değerlere kritik bir yaklaşım -sorunlar ve çözümler-. R. Kaymakcan, S. Kenan, H. Hökelekli, Ş. Arslan ve M. Zengin (Ed.), Değerler ve eğitimi uluslararası sempozyumu içinde (ss.203-214). DEM.

Karasar, N. (2010). Bilimsel araştırma yöntemi. (21. Bask1). Nobel.

Kılcan, B. (2013). Sosyal bilgiler öğretim programında yer alan değerlere ilişkin öğrenci algılarının incelenmesi. [Yayınlanmamış Doktora Tezi. Gazi Üniversitesi].

Kılcan, B. ve Üçarkuş, E. (2018). Eğitim Bilişim Ağı EBA dergilerinin değerler eğitimi açısından incelenmesi. Uluslararası Sosyal Bilgilerde Yeni Yaklaşımlar Dergisi, 2(1), 42-54.

Kurtoğlu, F. S. (2017). Âşık Veysel in şiirlerini değerler eğitimi açısından okumak. Türk Kültürü ve Hacı Bektaş Veli Araştırma Dergisi, 83, 101-123.

Kurtoğlu, F. S. (2019). Kök değerler açısından Hacı Bektaş Velî nin eserleri, Türk Kültürü ve Hacı Bektaş Veli Araştırma Dergisi, 89, 55-70

Kuşdil, M. E. ve Kağıtçıbaşı, Ç. (2000). Türk öğretmenlerinin değer yönelimleri ve Schwartz değer kuramı.Türk Psikoloji Dergisi, 15(45), 59-76.

Milli Eğitim Bakanlığı (2018). Matematik dersi öğretim programı (ilkokul ve ortaokul 1,2,3,4,5,6,7 ve 8. sinıflar). MEB Yayınları.

Milli Eğitim Bakanlığı (2019). Ders kitapları hakkında merak edilenler. https://ttkb.meb.gov.tr/meb_iys_dosyalar/2019_08/26180800_ders_kitaplari_hakkinda_brsr.pdf

Mindivanlı, E., Küçük, B. ve Aktaş, E. (2012). Sosyal bilgiler dersinde değerlerin aktarımında atasözleri ve deyimlerin kullanımı. Ĕğtim ve Öğretim Araştırmaları Dergisi, 1(3), 86-94.

Özden, Y. (2008). Eğitimde yeni değerler 'Eğitimde dönüşüm' (7. Bask1). Pegem.

Özensel, E. (2003). Sosyolojik bir olgu olarak değer. Dĕgerler Eğitimi Dergisi, 1(3), 217-239.

Özensel, E. (2007). Liseli kız ve erkek öğrencilerin değer yargıları ve Türk toplumunun temel toplumsal kurumlarına bakış açıları. R. Kaymakcan, S. Kenan, H. Hökelekli, Ş. Arslan ve M. Zengin (Ed.), Değerler ve eğitimi uluslararası sempozyumu içinde (ss.743-769). DEM. 
Paleg, K. (1998). Her anababanın bilmesi gereken on şey, yeni anababalar ve çocuğuna değer veren herkes için bir kılavuz. (Çev. H. Gürel). HYB.

Punch, K. F. (2011). Sosyal araştırmalara giriş: Nicel ve Nitel Yaklaşımlar, (Çev. D.Bayrak, H. B. Arslan ve Z. Akyüz). Siyasal.

Saygılı, G. (2015). Değerlerin tanımı, özellikleri ve sınıflandırılması, M. Gündüz (Ed.), Değerler eğitimi içinde (ss.1-18), Maya.

Sayın, V., Orbay, K. ve Altunay-Şam, E. (2019). 5. sınıf matematik ders kitabının değerlerimiz açısından incelenmesi, IBAD Sosyal Bilimler Dergisi, (özel sayı), 161-171.

Sefa, A. (2009). 7. sınıf ilköğretim matematik ders kitabının; Görsel, duyuşsal ve akademik yönden incelenmesi. [Yayımlanmamış Yüksek Lisans Tezi, Selçuk Üniversitesi]

Şahin, Ö. ve Başgül, M. (2019). Ortaokul matematik ders kitaplarında sosyal değerler. Dicle Üniversitesi Ziya Gökalp Eğitim Fakültesi Dergisi, 34, 90-104.

Şimşir, Z. ve Dilmaç, B. (2020). Değerlerin sınıflandırılması, H. Ekşi ve A. Katılmış (Ed.), Karakter ve Değerler Ĕgitimi içinde (ss.57-73), Nobel.

Sözmez, Ö. F. (2014). Atasözlerinin sosyal bilgiler programındaki değerler açısından incelenmesi. Zeitschrift für die Welt der Turken, 6(2), 101-115.

Sözmez, Ö. F. ve Akıncan N. (2019). Sosyal bilgiler öğretim programındaki yardımseverlik ve dayanışma değerlerinin ulusal gazetelerde yer alma düzeyinin incelenmesi. SBAD, 14(2), 802-815.

Tarhan, N. (2013). Güzel insan modeli. Timaş.

Tepecik, B. (2008). Sosyal bilgiler dersinde sorumluluk değerinin kazandırılmasına ilişkin öğretmen görüşleri. [Yayınlanmamış Yüksek Lisans Tezi, Anadolu Üniversitesi].

Theodorsan, G.A. \& Theodarsan, A. (1979). A modern dictionary of sociology. Barnes \& Noble.

Türk Sanayicileri ve İş İnsanları Derneği (1991). Türk toplumunun değerleri. Boyut.

Uzunkol, E. ve Karaca, D. (2019). İlkokul matematik ders kitaplarının içerdiği değerler bakımından incelenmesi. International Journal of Field Education, 5(2), 55-71.

Ülken, H. Z. (1969). Sosyoloji sözlüğü. Milli Eğitim Basımevi.

Yalar, T. (2010). Illköğretim sosyal bilgiler programında değerler eğitiminin mevcut durumunun belirlenmesi ve ögretmenlere yönelik bir program modülü geliştirme. [Yayınlanmamış Doktora Tezi, Mersin Üniversitesi].

Yılar, R. (2016). İlettiği değerler açısından ilkokul Türkçe ders kitaplarındaki metinler üzerinde incelemeler. Bayburt Eğitim fakültesi dergisi, 11(2) 490-506

Yıldırım, A. ve Şimşek, H. (2006). Sosyal bilimlerde nitel araştırma yöntemleri (6. Baskı). Seçkin. 


\section{EXTENDED ABSTRACT}

\section{Investigation of the Root Values in Mathematics Textbooks of Middle School and Imam Hatip Secondary Schools}

The ability of individual to live in a healthy, peaceful and happy manner within a certain society with other individuals is possible with the existence of the legal rules determined for that society as well as the values that the society believes, internalizes and is concerned about transferring them to the future generations. Values are generally defined as generalized behaviour that occured as the emotional dependence of people with eachother as well as generalized tendency to change one state to another, the belief about whether something is desired or not and the behavior or behavior patterns displayed by people that set a certain standard. The mission of gaining values that are accepted by everyone, to individuals is carried out from a young age primarily through the family and close environment and then through educational institutions. Undoubtedly, educational institutions take the lead in gaining value. Because here the acquisition of values education is done implicitly as well as systematically within a certain plan.

The values education activities carried out in educational institutions is generally based on the curriculum of the lessons at school. These programs are created by taking into consideration the innovations, technological developments and social needs of the era. By considering all these requirements and needs, all teaching programs in Turkey as well as mathematics curriculum were renovated in 2018. One of the most important innovations brought by this renewed program is root values. These root values are included in all education programs in connection with different disciplines.

Textbooks have an important place in gaining values to individuals. Because textbooks are seen as materials that help value education as well as mediating the transfer of the acquisitions in the curriculum. Based on this, this study was carried out in order to examine the mathematics textbooks prepared for middle schools and imam hatip secondary schools in terms of root values.

In the study designed in accordance with the qualitative research method, document analysis technique was used for data collection. Mathematics textbooks constitute the data collection source of the research. In the examination of the content in the books in terms of root values, practice and end-of-unit questions, topic and unit evaluation tests, and questions under the heading "You have the solution" were excluded, only the parts in the books where the lectures were made and examples were given. The data obtained from the books were analyzed in accordance with the descriptive analysis technique and classified by giving the page numbers of the root values in the work. Finally, as a result of these classifications the findings of the research were formed by determining the place of root values in the relevant books.

It was obtained that the most common values in the mathematics textbooks prepared for the middle school and imam hatip secondary schools respectively were; responsibility (34 times), love (29), benevolence (16), justice (13), friendship (6), patriotism (5), self-control (5). 4), patience (4), honesty (2) and respect (2). As we look at the cases where the root values are included on the basis of the class, it was observed that while the root values are found in the phase 5 and 6th grades, less root values are included in the 7th and 8th grades. Using the expressions in middle school and imam hatip middle schools mathematics textbooks in gaining these root values to students can be beneficial in the education of root values. However, the 
lack of a balanced distribution in the root values and then in the classes in the textbooks may disrupt the activity of gaining the root values to students. In this respect, it is recommended to make a balanced value distribution on the basis of both the root value and the classes mentioned above in the future mathematics textbook preparation studies.

\section{(c) (7) (9)}

"International Journal of New Approaches in Social Studies - IJONASS" is licensed under a Creative Commons Attribution-NonCommercial-ShareAlike 4.0 International License. 